\title{
The institutionalization of the geography of education: An international perspective
}

Silvie R. Kučerová, Sarah L. Holloway, Holger Jahnke

Abstract: The geography of education is a young field of research. This article makes two innovative contributions to knowledge about the evolution of this body of work. First, it presents a three-fold history of the field, delineating distinct phases in its development. Second, it draws out both linkages across, and disparities between, geographies of education in different language traditions. The analysis includes longer established German-language, Francophone and Anglophone oeuvres, as well as more recent Eastern European and international research. In combination, this attention to the temporality and spatiality of geographical debate about education provides a unique introduction to the field.

Keywords: geography of education, geographical knowledge, history of geography

\section{Introduction}

Space, place, scale and environment are core concepts that differentiate geography from other social sciences dealing with education. These other disciplines may indeed consider space as one of the factors influencing educational processes, but in geography space (in particular) has long been a central organising concept that lies at the heart of disciplinary research interest in education. This ongoing interest in space in geography does not imply stasis in disciplinary thinking, however, as the conceptualization of spatiality within the discipline has fundamentally changed over the past 50 years. Notably, we have witnessed shifts from absolute space (conceived as a passive entity in which phenomena are located and ordered) through relative space (a tool considering social and economic structures) to relational 
space (an entity which is lived, perceived by individuals, but at the same time constructed in their minds and produced in actions), as different philosophical traditions have reshaped geographical thinking (Gregory, 2009).

The aim of this paper is to explore shifts in geographical thinking about education. There are two core parts to the argument. First, the paper explores the growing institutionalization of geographic research into education over the past 60 years. It identities three key phases: (1) The origins of interest in education and initial efforts to establish a research field; (2) The developing codification of the research area as it began to gain greater recognition within the discipline; and (3) Contemporary manifestations of geographies of education in social scientific research and practice. Second, to explore spatial as well as temporal specificity in the development of the field, the paper examines both key differences between, and the linkages across, research in different language traditions as they shift over time. This analysis considers not only German-language, Francophone and Anglophone bodies of work which have the longest lineage, but also how they articulate with more recent Eastern European and other international research on the geography of education.

In combination, this attention to the temporality and spatiality of geographical debate about education provides a unique introduction to the field and offers a point of departure for future research. This should not only be of value to geographers wishing to reflect on the development of their field, but also usefully situate geographical research for other social scientists so they might understand how spatial research can contribute an important piece to the wider mosaic of interdisciplinary studies on education.

\section{Geography of Education: Naming the Field}

The term "geography of education" (Bildungsgeographie / Geographie des Bildungswesens; géographie de l'instruction / géographie de l'éducation) first appeared in the 1960s and the 1970s, emerging in the three locations where geography developed as a modern academic discipline: Germany, France and the United Kingdom.

From the late 1960s onwards, the importance of geography within the research on education was invoked by geographers in German speaking countries - especially by Robert Geipel at the universities of Frankfurt and Munich (Geipel, 1965; Geipel, 1968) and later by Peter Meusburger (Meusburger, 1976; Meusburger, 1980; Meusburger, 1998) in Innsbruck (Austria) 
and Heidelberg (Germany). At its beginnings, German speaking Bildungsgeographie was founded as an applied geography of spatial planning, focussing on the analysis of spatial inequalities in the provision and the accessibility of public schools and other educational institutions (Meusburger, 2015).

Almost in the same period, Francophone authors endorsed "la géographie de l'instruction" or "la géographie de l'éducation" (Debesse, 1972). Notwithstanding similarity in timing, the roots of the geography of education were somewhat different in France. Between 1969 and 1978, Maurice Debesse co-edited multiple volumes of Traité des Sciences Pédagogiques, from where he developed the idea of a geographical approach to the 'foundation disciplines of education' (Brock, 2016, p. 15). Having trained as a geography teacher, Debesse was nominated professor for pedagogy at the Sorbonne and his understanding of the géographie de l'éducation was rooted in the idea of comparative education studies within the field of education research.

Even though the German and the French geographical approaches to education were epistemologically very different, there was nevertheless an exchange of ideas between them in the 1970s. In 1978, the French journal Annales de Géographie published a review (Vassal, 1978) of Peter Meusburger's state of the art article, which had been published two years before in the Austrian journal Mitteilungen der Österreichischen Geographischen Gesellschaft (Meusburger, 1976).

The dominance of English as an academic language is evident, however, in (an Anglophone) tendency to overlook German-language and Francophone research, and attribute the institutionalization of the geography of education to the direct appeal to the international geographical community by two Englishmen, Gerald H. Hones and Raymond H. Ryba, at the International Geographical Congress in Canada in 1972. Their conference paper, entitled "Why not a geography of education?", and the subsequent print article in the American Journal of Geography (Hones \& Ryba, 1972), argued that many studies seek to investigate the differences in education between various states or regions, using the explanations like "geographic factors" or "determinants of national character" (p. 136), without supporting evidence or data. In accordance with the then current trend to critique subjective description in geographic research, the authors warned against a simplified view of the complexity of educational systems by the other disciplines that "are in mistaken belief that they could equally well supply the geographical approach" (p. 136). Referencing Anderson \& Bowman (1966) 
and Hägerstrand (1971), they encouraged geographers to undertake spatial planning in education in line with the then modern theoretical models and techniques of locational analysis. Moreover, they also questioned why a scientific discipline of the geography of education had not yet been established, when systematic fields such as religious or electoral geography were already in existence.

After this intervention, greater attention was payed to spatial aspects in education by Anglophone geographers in the United Kingdom (e.g. Brock, 1976), the United States and the wider English-speaking world. To some extent, it might be possible to argue that Anglophone geography during this period simply needed to catch up with German-language and Francophone traditions. Between 1973 and 1981 G. H. Hones and R. H. Ryba edited five bulletins on the geography of education, inviting insights from various researchers in the field. For example, Marsden (1977) produced a broad classification of English-written studies concerning spatial aspects of schooling noting, in reference to Meusburger's (1976) overview article, that: "The only summary of the field to date is in German" (Marsden, 1977, p. 21). Nevertheless, there were also key points of intellectual exchange. American research by this point already had a significant tradition of studying spatial differences in urban education, utilizing the social ecology framework first developed by scholars at the University of Chicago. This paradigm of social ecology not only eventually resulted in the founding of the sociology of education (Coleman, 1988), but also influenced German-language geography of education. Geipel (1968), who applied the Chicago school concept of "educational land use" to his study of educational disparities and "educational deserts", is an example of this trend (Meusburger, 1998).

In sum, three language traditions emerged during this early phase in naming the geography of education. Francophone practice was initially inspired by comparative educational focus on different education systems, while German-language and Anglophone research placed a greater emphasis on the spatial analysis of educational provision within nations, identifying relationships between space/place, population and educational provision. In a time centrally shaped by the quantitative revolution, research commonly involved the statistical analysis of spatial data in order to enhance spatial planning of the school system, maximising the efficiency of school provision while attending to pupils' travel needs (Marsden, 1977; Meusburger, 2015). In essence, stress was put upon the application of knowledge in practice and this led to the creation of expert knowledge and maps for executive bodies. 


\section{Codifying the Geography of Education}

This picture, in which the geography of education developed rather independently in different language traditions, with only particular ideas or individuals producing notable moments of intersection, continued through the subsequent codification of the geography of education. The German school was very active at this point. Meusburger $(2015$, p. 166) declared that "in the 1970s and 1980s dozens of German, Austrian and Swiss geographers got involved with geography of education" and as early as 1983 a formalized working group was established within the German Society for Geography (DGfG). Since the 1980s, Bildungsgeographie has been a well-established sub-discipline within German speaking human geography, with significant research at the universities of Heidelberg, Osnabrück, Gießen, and Münster. Peter Meusburger's chair at the University of Heidelberg has been the centre for Bildungsgeographie for several decades; here, he supervised a significant number of PhD theses covering different geographical questions concerning primary, secondary and tertiary education in Germany, the U.S. and Italy (for example Schmude, 1988; Kramer, 1993; Weick, 1995; Freytag, 2003; Jöns, 2003 and Jahnke, 2005). A very important step in the institutionalization of the subdiscipline in German-speaking geography was the publication of the first textbook entitled "Bildungsgeographie" in 1998, a remarkable volume of more than 500 pages summarizing in German the international and interdisciplinary state of research on "Knowledge and Education in a Spatial Perspective".

German success in establishing the geography of education as a sub-discipline was not reflected in Francophone or Anglophone geography. French research, though important in the early development of the field, became less visible to the German-language and Anglophone scientific communities during the following decades. In Anglophone geography, the research into the geography of education was slow to gain recognition. This is evidenced through its exclusion from, and subsequent shifting inclusion within, the Dictionary of Human Geography. First published in 1981 by a group of British geographers led by $R$. J. Johnston, this dictionary was designed to "enable the reader to develop the wider context of a term rather than just obtain an independent statement of its meaning" (Johnston, Gregory, Haggett, Smith \& Toddart, 1981, p. xi). In the first edition, there was no entry on "Geography of Education": this reflected the low status of research on this topic in the Anglophone literature, despite the fact that many studies were in existence. There was an entry on "Education", but this only encapsulated research about geographical education (i.e. the teaching of geography). 
The entry "Geography of Education" first appeared in the significantly revised and expanded second edition of the Dictionary of Human Geography which demonstrated increased awareness of non-Anglophone research (Johnston, Gregory \& Smith, 1986). The author of the entry "Geography of Education" was British geographer Rex Walford, a lecturer in geography and education at Cambridge, where he led the training of geography teachers. Not surprisingly, he also authored the entry "Geography in Schools" which encompassed research on the curriculum and teaching geography. In comparison to many entries in the dictionary defining the other sub-disciplines (e.g. electoral geography - see also Hones \& Ryba, 1972 on this topic above), the entry on "Geography of Education" did not begin with a definition of the subject of research, rather it commenced with a reflection on its short history: "Studies in the geography of education were relatively insignificant and uncoordinated until the 1970s" (Walford, 1986, p. 125). Following an enumeration of early works, predominantly from the German- and Englishspeaking world (see section 2), Walford (1986, p. 125) then sought to define his research subject as follows:

"(a) the study of the distribution and variation of educational phenomena at a variety of scales from global to local,

(b) historical studies in the growth and diffusion of educational provision and in the factors affecting this,

(c) studies in the principles of school location and in the creation of catchment areas".

Last, the author added a recently emerging strand: "the implications of uneven public resource provision in education" (p. 125). This was a sign of research to come over the next two decades.

Subsequent editions of the Dictionary of Human Geography which span the turn of the twenty-first century, with those in later years being edited by male and female, British and North American geographers, highlight the importance of two influences in shaping the field. First, it is notable that neoliberal shifts in public policy have had clear implications for geographic research. The 1980s was a decade when economic liberalism started to prevail in Western geopolitical bloc countries and the ideology influenced the realm of education. Governments abandoned strict equity in the spatial distribution of public-school services and catchment areas. The countries supported economically more "effective" school markets driven by educational consumers (pupils and especially their parents) (Brock, 2016; Taylor, 2001; Koinzer, Nikolai \& Waldow, 2017). Compared to the previously socially more gener- 
ous era in some of the states (e.g. Scandinavia), less profitable peripheral rural schools were threatened with closure (Kvalsund, 2009). In the other states - both in the geopolitical West and East - the trend of closing small elementary schools continued as a result of the 1970s "modernization" of educational systems and concentration of educational functions in larger settlement units (Kučerová, Dvořák, Meyer \& Bartůněk, 2020; Meusburger, 2015; Ribchester \& Edwards, 1998). However, the problems caused by operating public schools on market principles were most evident in urban space. Here it led to the deepening of a sharp differentiation between schools in relation to pupils' residential environment and to social segregation (e.g. by class, ethnicity). These empirical changes in the nature of education in much of the Global North were reflected in a changing research agenda. Initially, there were many purely quantitative studies which employed statistical analysis to measure the consequences of changes in the operation of the education system for regional and local socio-economic environments (Bradford, 1991).

A second change, however, centred on philosophical shifts in geographical thinking then intersected with the neoliberal landscape in education. In accordance with the general orientation in human geography from the 1980s onwards, geography of education broadened from the spatial science perspective that had supported the technical planning of education systems. Critical human and social science was now embraced, prompting greater attention to the political economy of provision and individual people's experiences of education. This phase has seen the explicit definition of the geography of education as: "The study of spatial variations in the provision, uptake and outputs of educational facilities and resources" (Johnston, 1994, p. 156). The same definition was reproduced in the fourth edition (Johnston, Gregory, Pratt \& Watts, 2000). Since then, the fifth edition (Gregory, Johnston, Pratt, Watts \& Whatmore, 2009), though now over ten years old, has stressed the study of variations in the quality, not simply provision of education, under the definition: "Studies of the geography of education focus on spatial variations in the quality of and outputs from educational resources" (Johnston, 2009, p. 186). This may not seem like a seismic change, but in tandem with shifting philosophical traditions, it marks a shift from a purely spatial focus on the accessibility of schools, towards efforts to understand their spatial allocation as results of political processes and dominant ideologies, and to consideration of the social and cultural accessibility and consequences of educational facilities as public goods (e.g. Ansell, 2002; Warrington, 2005). In terms of research process, quantitative methods remained important, but this phase also saw a blossoming of qualitative research. 
In overview, this section demonstrates that Bildungsgeographie was codified as a vibrant sub-discipline relatively early in German geography. The codification of the geography of education as a field of research was much later in Anglophone geography, although in recent years the frame of research has widened in response to both political and philosophical change. It is particularly noteworthy, however, that its process of institutionalisation in Anglo-American geography, not least through the pioneering efforts of Walford (1986), emerged in isolation from the earlier, and active, German School. For a long time, Anglophone geography - whether through intellectual arrogance or limited linguistic competence - did not seek to learn from its mainland European counterparts (cf. Meusburger, 2015). Moreover, while in Germany Bildungsgeographie reached sub-disciplinary status, in Anglo-American geography the geography of education was codified as a field of study without necessarily developing the institutional architecture (e.g. dedicated journals) required to mark it as an established sub-discipline.

\section{Dispersing and Diversifying the Geography of Education in the Twenty-first Century}

\section{Dispersing geographical thought}

In the contemporary era, the geography of education remains a vibrant field of interest in the three language traditions from which it emerged. In Germany, geography of education research is centred around the universities of Flensburg, Karlsruhe and Freiburg. A new textbook entitled "Bildungsgeographie" (Freytag, Jahnke \& Kramer, 2015), a recent state of the art article (Freytag \& Jahnke, 2015a), entries in standard geography dictionaries (Meusburger, 2001) and human geography textbooks (Jahnke, 2014) witness the establishment of the sub-discipline and serve as references for the German speaking community of researchers, university teachers and students interested in the field of geography of education.

Though French research had been somewhat hidden from non-native speakers in previous decades, this tradition is once again making an important contribution on the international stage (Wayens, Marissal \& Delvaux, 2017). A large part of the recent research focuses on the ambiguous outcomes of a territorialized education policy, which has become part of a broader urban intervention policy, and was designed to mitigate social exclusion in large social housing areas (Barthes, Champollion \& Alpe, 2018; Giband, 2019). Especially in urban contexts, geographers of education critically examine the consequences of the normative policy of "mixite sociale" 
and the interrelation between school segregation and residential segregation (Audren \& Baby-Collin 2017; Douchy 2017). The new Francophone geographie de l'enseignement has extended to Belgium and directly links to international debates. Empirical research projects are carried out not only in France and Belgium (Marissal 2017; Danhier \& Devleeshouwer 2017), but also the United States (Nafaa, 2017).

In Anglophone geography, literature on the topic is burgeoning (Holloway \& Jöns, 2012; Waters, 2017). In 2019, the Royal Geographical Society in the UK launched a 'Geography and Education Research Group' which, in a move reminiscent of Walford's (1986) contributions to the Dictionary of Human Geography, will have a dual focus on 'Geographies of Education' and 'Geographical Education'. Moreover, there have been three international conferences on the Geographies of Education at Loughborough University in the UK: the growth of academic mobility means that these were both coconvened by British and German-born geographers working in Britain and attended by pan-European researchers. This trend is indicative of growing interconnection between different language traditions.

This phase of growing interests in education in its traditional centres has been matched by spatial dispersion of the field. In Europe, geographical scholars in every region faced different challenges concerning spatial inequalities in education. Following the fall of politically bipolar world in 1990, and with the wide spread of English as the predominant scientific language, ideas relating to geography of education also diffused across the European continent to states that did not have the strong German and British background in traditional scientific schools. This dispersal of interest has seen new research into the impact diverse political regimes have had on educational landscapes in different post-socialist countries, including Czechia, Hungary, Poland and Slovakia. Direct links between established and these newly emerging traditions are apparent in this dispersal: for example, Czech geographer Arnošt Wahla drew on Meusburger (1976) in presenting the field in Czechia as part of population geography (Wahla, 1988). This did not mean, however, that geography of education was simply transplanted into Eastern European countries as a rounded field. Rather, isolated studies engaging with the spatial aspects of education started to appear here at the beginning of the $21^{\text {st }}$ century.

Over the past two decades, a number of lines of research have emerged in Eastern European nations. Spatial analyses of the distribution and changes in the provision of schools are one developing thread (e.g., Lauko, Gurñák, 
Križan \& Tolmáči, 2011). These quantitative studies make use of rich statistical databases about formal education, and this allows them to trace detailed changes over time and represent them in cartographic form. Another line of research builds upon Eastern European traditions of research into commuting and the delimitation of catchment areas for various institutions. This has prompted research on the regions schools serve (Hampl, 2004; Kučerová, Bláha \& Kučera, 2015), computer modelling of school availability using geographic information systems (Kučerová, Mattern, Štych \& Kučera, 2011) and time-spatial frameworks of the movement of people within areas (Ouředníček, Špačková \& Feřtová, 2011). Much of this research is centred on urban areas, but in Czechia there is also a tradition of research of rural schooling. Taken together, it is evident that the majority of current studies within geography of education in these countries are concerned with local administration and policy, and how it might shape human capital and regional development (Bajerski, 2015; Gyuris, 2019; Kučerová, Bláha \& Pavlasová, 2015). Interestingly, although social inequalities that relate to spatial injustices in educational provision have been a key concern in the geography of education elsewhere, in Eastern Europe these issues are mostly incorporated into sociology (Kovács, 2012; Nekorjak, Souralová \& Vomastková, 2011). Nevertheless, the boundaries between disciplines are becoming more blurred as firstly the educational sciences (Trnková, Knotová \& Chaloupková, 2010), and subsequently geography, have crossed traditional research boundaries to produce more complex interpretations of processes and mechanisms shaping the educational landscape (Kučerová, Dvořák, Meyer \& Bartůněk, 2020).

On the world stage, education has become an increasingly globalised issue (Harber, 2014; Mallinson, 1980), prompting a growth of research interest. This includes studies dealing with: comparison of the quality of education between states and regions; differences in access to education and knowledge; issues of curriculum design that is deliberately or unintentionally unjust; and education's links to credentialism, employability, and workforce policy. Moreover, research into spatial aspects of education is not limited to researchers in the Global North. Although, publications by authors from the Global South are not so frequent in journals edited in Euro-American space, their works have often been part of edited international publications, e.g., Forsey, Davies \& Walford (2008); Koinzer, Nikolai \& Waldow (2017). Nevertheless, the spreading of knowledge and information about research schools from these parts of the World are still at the very beginning of international scientific communication. 
The dispersal of interest into spatial aspects of education has also traversed disciplinary boundaries. The spatial turn in the social sciences (especially sociology, economics and educational sciences - Warf \& Arias, 2009) has led to a growing number of publications from education science which could be relevant for the geography of education (Dvořák, Starý \& Urbánek, 2015). These researchers may identify themselves with thematically close social disciplines such as anthropology and even more sociology of education (Sadovnik, 2011) or, if using more exact spatial information and geographical information systems, refer to social cartography (Green \& Reid, 2014; Corbett \& Donehower, 2017). Nevertheless, it is clear that this growing body of interdisciplinary research can enhance geographers' understanding of education. An exemplar of this is the strong influence of Scandinavian scholars, from both educational and geographical backgrounds, who explore disadvantages and inequalities in education within rural and remote areas (e.g., Solstad, 1997; Kvalsund, 2009; Åberg-Bengtsson, 2009; Autti \& Hyry-Beihammer, 2014; Tantarimäki \& Törhönen, 2017).

\section{Diversifying geographical research}

This spread of the geography of education, in both spatial and disciplinary terms, has been matched by diversification in its object of research. In many nations, interest in education has spread across numerous sub-disciplines of human geography, such as economic geography, migration studies, urban geography, children's geographies. Although these researchers produce works directly linked to the geography of education, they may not necessarily apply this label to themselves (e.g. Dostál \& Markusse, 1989; Barakat, 2015). Nevertheless, the result is that twenty-first century definitions of the field are notably broader than their late twentieth century counterparts. In an Anglophone context, Holloway \& Jöns (2012, p. 482) argue that: "Geographies of education and learning consider the importance of spatiality in the production, consumption and implications of formal education systems from pre-school to tertiary education and of informal learning environments in homes, neighbourhoods, community organisation and workspaces." The fact that this definition shares some similarities with the recent characterisation of Bildungsgeographie, as centred on institutions, individuals and practices in primary, secondary and tertiary, formal and nonformal education (Freytag, Jahnke \& Kramer, 2015), suggests that some of the distinctions between language traditions are fading. Nevertheless, Freytag et al.'s (2015) six-fold identification of thematic priorities in Bildungsgeographie - (1) location of education institutions; (2) participation in education and social inequality; (3) education and territorialisation; (4) education and develop- 
ment; (5) education and migration as well as (6) education and the economy - also demonstrates some ongoing differences between traditions. Notably, in placing the location of education institutions first, it points to the greater longevity of research on mixed methods of spatial analysis and qualitative methodologies in German geography, a trend reflected in current research in Eastern European geography of education (e.g., Kučerová, Mattern, Štych \& Kučera, 2011; Kučerová, Bláha \& Pavlasová, 2015). Theoretically, Freytag \& Jahnke (2015a) in their state-of-the art article have responded to the lack of theoretical foundations in the German tradition of Bildungsgeographie through an elaboration of six key concepts from human geography that might inform the geography of education. All of these concepts - (1) spatial disparities; (2) mobility; (3) scale; (4) bordering and regionalization; (5) embeddedness and networking as well as (6) production and representation of educational spaces - could also be argued to be of importance in other language traditions. Nevertheless, there are ongoing differences in their relative importance: for example, the emphasis on mobilities has received greater attention than spatial patterns in Anglophone research.

This empirical diversity in research focus reflects both ongoing interest in long-established issues and new stimuli for research. Schooling remains important, with a vital and enduring focus on changes in regional and local conditions of schooling in relation to education policy decisions. In continental Europe, renewed attention is being given to spatial inequalities in public school provision, with special attention attributed to school closure in rural areas. This is matched by concern, also shared in Anglophone research, with growing school segregation in urban areas (Jahnke, Kramer \& Meusburger, 2019; Basu, 2007; Bajerski, 2015; Freytag \& Jahnke, 2015b; Giband, 2019; Groos, 2015; Gyuris, 2019; Jahnke, 2019; Nast, 2015; Nieszery, 2015). In particular, attention has been given to the local and regional consequences of school marketization, including the formation of spatial and social differences under school competition and parental choice, in a landscape where educational quality is defined by the rating of school facilities and performance (Noreisch, 2007; Jahnke \& Hoffmann, 2017). Many researchers continue the tradition of using quantitative methods for spatial planning (Johnston, Burgess, Wilson \& Harris, 2006; Taylor, 2001), but this is now augmented by in-depth, often qualitative, studies of the contested and contingent nature of state policy, and the difference the peopling of the state makes to the emergence of policy in practice (Holloway \& PimlottWilson, 2012). Moreover, the strength of research on Children, Youth and Families in the Anglophone tradition and Geographien der Kindheit and Jugendgeographien in German research, has seen greater attention paid to the 
role of the formal and informal curriculum in shaping young people's and parents' spatial and social identities, reflecting on both their experiences of education in their present and its implications for their future life-worlds (Sidorov, 2009; Bauer, 2010; Bauer \& Landolt, 2018, Schaefli, Godlewska \& Lamb, 2019; Kučerová, Kučera \& Novotná, 2018; Holt \& Bowlby, 2019).

Higher education has attracted increasing attention, both as geographers are interested in universities' economic and social impacts on their home regions (Smith, 2008), and as the growth of network and mobility perspectives in geography have highlighted global interconnection in the burgeoning higher education system, and the crucial role played by the international mobility of staff and students (Waters, 2017; Jöns, 2018). By contrast, attention to pre-school services and out-of-school childcare provision in Anglophone research reflects, in part, the strength of feminism within the discipline, not least as it has turned attention to questions about social reproduction (Mahon, 2005; Gallagher, 2014; Holloway \& Pimlott-Wilson, 2019). In German academica, this form of work is more likely to be undertaken in education science, interdisciplinary gender studies or feminist geographies, and geographies of childhood.

Perhaps even more striking, however, is the move to incorporate diverse forms of informal, alternative, supplementary and work-based education within geographical research. This includes, for example, informal education through youth organisations (Mills, 2016), alternative provision such as Forest Schooling, Steiner Schools and Care Farms (Kraftl, 2014; PimlottWilson \& Coates, 2019), supplementary education such as private tuition (Holloway \& Kirby, 2020), and work-based training, including volunteering, apprenticeships, and MBAs (Hall, 2008; Baillie Smith \& Laurie, 2011; Gough, Langevang, Yankson \& Owusu, 2019). This attention to informal, alternative, supplementary and work-orientated education signals growing interest in different educational ethoses. Some of these forms of provision such as private tuition or apprenticeships - can tie education instrumentally to employability. Other forms - such as home schooling, extra-curricular activities or youth organisations - can reflect a rejection of neoliberal educational values, a strategic response to them, or a desire to create morallyrounded human beings (Holloway \& Kirby, 2020; Kraftl, 2014; Jahnke \& Hoffmann, 2017; Kostelecká \& Hána, 2017).

Considering the broad research interests of geographers of education, it seems to be a logical result that the term the 'geography of education' is often now pluralised. For example, Holloway \& Jöns (2012) refer to a whole spec- 
trum of "Geographies of Education (and Learning)", while Jahnke, Kramer \& Meusburger's (2019) entitled their recent book, which drew together authors from different national contexts and varied research perspectives, "Geographies of Schooling". It would seem that the dispersion and diversification of geographical research on education is well advanced.

\section{Conclusion}

The purpose of this article has been to explore temporal shifts in the institutionalisation of the geography of education, while simultaneously attending to spatial variations in the form this research takes. The temporal analysis demonstrates that, since at least the 1960s, there has been a growth of work on the geography of education, and this field of research has been increasingly codified into geographical knowledge. The final inventory of studies is undoubtedly broad, reflecting a deliberate diversification in research foci that reflect both new empirical trends and changing philosophical approaches. However, in the context of disciplinary geography as a whole, the community which researches this topic is still rather small in size. Indeed, there remain spatial differences in the extent to which the field is recognised as a sub-discipline. Our analysis demonstrates that this status was gained early in the German language tradition, but in the British context at least, geographies of education are increasingly being institutionalized as an interesting field of study, but few practitioners there would argue that is has gained sub-disciplinary status.

This spatial variability in the subject's institutionalization is matched by an ongoing, but rapidly diminishing, variability in core research objectives between language traditions. These differences not only reflect a path-dependency in the described research traditions, but also crucially the impact of current education policies in the respective countries. For example, there is more emphasis in German-language geography on spatial differences in formal education offers, with special attention attributed to new spatial constellations of formal and nonformal education at the local level in urban and rural contexts. This follows policy innovation centred on the creation of socalled education landscapes and recent policy innovation in the provision of all-day-schooling. In Anglophone contexts, greater attention is focused on the neoliberalisation of education and its impact on equality, as well as the growth of supplements for, and alternatives to, this instrumental form of provision, since such questions are more politically pertinent. Nevertheless, these differences are much less stark than in previous decades as a more common research agenda is emerging across German-language, French- 
language, Anglophone and even Eastern European research. This is shaped in no small measure by the growing international community of researchers in geographies of education: their linkages are enhanced both by short-term mobility to attend commonly organised international conferences, as well as longer-term migration for work in different nations (most notably as facilitated by freedom of movement in the EU).

It is also timely to reflect on the field's position in relation to other disciplines which research education. The geography of education is not an equivalent either of the sociology of education or the anthropology of education. It does not act as a substitute for research in the educational sciences. Nor is it a simple empirical tool projecting educational reality into maps. Rather, it introduces a spatial prism to the complex reality in the sociopsychological-cultural processes of education. Although social science disciplines have passed through a "spatial turn", their newfound emphasis on space must not lead to the displacement of geography as this would impoverish understanding. On the contrary, broader interest in spatiality should help to ease interdisciplinary communication and understanding.

\section{Acknowledgements}

Silvie R. Kučerová would like to thank the Czech Science Foundation (project No. 20-18545S) and the European Union, European Social Fund and the Ministry of Education, Youth and Sports of the Czech Republic (Project Smart City - Smart Region - Smart Community - CZ.02.1.01/0.0/0 .0/17_048/0007435) for the financial support of this paper.

Sarah Holloway would like to thank The Leverhulme Trust (RPG-2018335) for funding her research time on this paper.

\section{References}

Åberg-Bengtsson, L. (2009). The smaller the better? A review of research on small rural schools in Sweden. International Journal of Educational Research, 48, 100-108. Anderson, C. A., \& Bowman, M. J. (Eds.). (1966). Education and economic development. London: Frank Cass.

Ansell, N. (2002). 'Of course we must be equal but... ': Imagining gendered futures in two rural southern African secondary schools. Geoforum 33, 179-94.

Audren, G., \& Baby-Collin, V. (2017). Ségrégation socio-spatiale et ethnicisation des territoires scolaires à Marseille. Belgeo 2-3.

Autti, O., \& Hyry-Beihammer, E. K. (2014). School closures in rural Finnish communities. Journal of Research in Education, 29(1), 1-17.

Baillie Smith, M., \& Laurie, N. (2011). International volunteering and development: 
Global citizenship and neoliberal professionalisation today. Transactions of the Institute of British Geographers, 3 (4), 545-559.

Bajerski, A. (2015). Erosion of the school catchment system as local policy: The case of Poznań, Poland. KEDI Journal of Education Policy, 12(1), 41-60.

Barakat, B. (2015). A 'recipe for depopulation'? School closures and local population decline in Saxony. Population, Space and Place, 21(8), 735-753.

Barthes, A., Champollion, P., \& Alpe, Y. (Eds.). (2018). Evolutions of the complex relationship between education and territories. Volume 1. London and Hoboken NJ: ISTE and John Wiley \& Sons.

Basu, R. (2007). Negotiating acts of citizenship in an era of neoliberal reform: The game of school closures. International Journal of Urban a Regional Research, 31(1), 109-127.

Bauer, I. (2010). Jugendgeographien. Ein subjekt- und handlungsorientierter Ansatz in Theorie und Praxis. Braunschweig: LIT Verlag.

Bauer, I., \& Landolt, S. (2018). Introduction to the special issue "Young People and New Geographies of Learning and Education". Geographica Helvetica, 73(1), 43-48.

Bradford, M. (1991). School-performance indicators, the local residential environment, and parental choice. Environment and Planning A, 23(3), 319-332.

Brock, C. (1976). A role for geography in the service of comparative education. Compare, 6(1), 35-36.

Brock, C. (2016). Geography of education: Scale, space and location in the study of education. London and New York: Bloomsbury Academic.

Coleman, J. S. (1988). Social capital in the creation of human capital. American Journal of Sociology, 94, 95-120.

Corbett, M., \& Donehower, K. (2017). Rural literacies: Toward social cartography. Journal of Research in Rural Education, 32(5), 1-13.

Danhier, J., \& Devleeshouwer, P. (2017). School choice and local embeddedness in Brussels: The neighbourhood effect assessed through administrative files. Belgeo 2-3. Debesse, M. (1972). Pour une geographie de l'education. In Traité des Sciences Pédagogiques 3: Pédagogique Comparée (pp. 401-409). Paris: Presses Universitaires de France.

Dostál, P., \& Markusse, J. (1989): Rural settlements networks and elementary service provision: Two scenarios for the matching of demand and supply. In G. Clark, P. Huigen, \& F. Thissen (Eds.), Planning and the future of the countryside: Great Britain and the Netherlands. Netherlands Geographical Studies.

Douchy, M. (2017). Les inégalités socio-spatiales d'éducation au prisme de l'action éducative locale française: le cas de la réforme des rythmes scolaires dans une ville française. Belgeo 2-3.

Dvořák, D., Starý, K., \& Urbánek, P. (2015). Škola v globální době. Proměny pěti českých základnich škol. Prague: Karolinum.

Forsey, M., Davies, S., \& Walford, G. (2008). The globalisation of school choice? Oxford: Symposium.

Freytag, T. (2003). Bildungswesen, Bildungsverhalten und kulturelle Identität: Ursachen für das unterdurchschnittliche Ausbildungsniveau der hispanischen Bevölkerung in New Mexico. Heidelberger Geographische Arbeiten: Vol. 118. Heidelberg: Geographisches Institut der Universität. 
Freytag, T., \& Jahnke, H. (2015a). Perspektiven für eine konzeptionelle Orientierung der Bildungsgeographie. Geographica Helvetica, 70, 75-88.

Freytag, T., \& Jahnke, H. (2015b). Schulen und sozialräumliche Fragmentierung in städtischen Quartieren. Berichte. Geographie und Landeskunde, 89(2), 109-120.

Freytag, T., Jahnke, H., \& Kramer, C. (2015). Bildungsgeographie. Darmstadt: Wissenschaftliche Buchgesellschaft.

Gallagher, A. (2014). The ,caring entrepreneur'? Childcare policy and private provision in an enterprising age. Environment and Planning A, 46(5), 1108-1123.

Geipel, R. (1965): Sozialräumliche Strukturen des Bildungswesens: Studien zur Bildungsökonomie und zur Frage der gymnasialen Standorte in Hessen. Frankfurt am Main: Diesterweg.

Geipel, R. (1968). Bildungsplanung und Raumordnung: Studien zur Standortplanung von Bildungseinrichtungen und zu räumlichen Aspekten des Bildungsverhaltens in Hessen. Frankfurt am Main: Diesterweg.

Giband, D. (2019). From republican spaces of schooling to educational territories? The problematic emergence of educational territories in postdecentralized France. In H. Jahnke, C. Kramer, \& P. Meusburger (Eds.), Geographies of schooling. Knowledge and space, Vol. 14 (pp. 75-93). Cham: Springer.

Green, B., \& Reid, J. (2014). Social cartography and rural education: Researching space(s) and place(s). In S. White, \& M. Corbett (Eds.), Doing Educational Research in Rural Settings (pp. 26-40), London and New York: Routledge.

Gregory, D. (2009). Geography. In D. Gregory, et al., The dictionary of human geography. $5^{\text {th }}$ edition (pp. 287-295). Malden, MA: Blackwell.

Gregory, D., Johnston, R., Pratt, G., Watts, M., \& Whatmore, S. (Eds.). (2009). The dictionary of human geography. $5^{\text {th }}$ Edition. Chichester: Blackwell.

Groos, T. (2015). Soziale Schulprofile in Zeiten wachsender Schulsegregation. Ansätze einer bedarfsgerechten Ressourcenverteilung. Berichte. Geographie und Landeskunde, 89(2), 121-141.

Gough, K, Langevang, T, Yankson, PWK, \& Owusu, G (2019). Shaping geographies of informal education: A global South perspective. Annals of the Association of American Geographers, 109(6), 1885-1902.

Gyuris, F. (2019). Ideology, spatial planning, and rural schools: From interwar to communist Hungary. In H. Jahnke, C. Kramer, \& P. Meusburger (Eds.), Geographies of schooling. knowledge and space, Vol. 14 (pp. 97-124). Cham: Springer.

Hägerstrand, T. (1971). Introduction: Quantitative techniques for the spread of information and technology. In T. Hägerstrand, \& A. Kuklinski (Eds.), Information systems for regional development. Lund studies in geography series 8: Human Geography (pp. 1-4). Lund: The Royal University of Lund.

Hall, S. (2008). Geographies of business education: MBA programmes, reflexive business schools and the cultural circuit of capital. Transactions of the Institute of British Geographers, 33(1), 27-41.

Hampl, M. (2004). Současný vývoj geografické organizace a změny v dojižd’ce za prací a do škol v Česku. Geografie, 109(3), 205-222.

Harber, C. (2014). Education and International Development. Theory, Practice and Issues. Oxford: Symposium Books. 
Holloway, S. L., \& Jöns, H. (2012). Geographies of education and learning. Transactions of the Institute of British Geographers, 37(4), 482-488.

Holloway, S. L., \& Pimlott-Wilson, H. (2012). Neoliberalism, policy localisation and idealised subjects: A case study on educational restructuring in England. Transactions of the Institute of British Geographers, 37(4), 639-654.

Holloway, S. L., \& Pimlott-Wilson, H. (2019). Schools, families, and social reproduction. In H. Jahnke, C. Kramer, \& P. Meusburger (Eds.), Geographies of schooling. Knowledge and space, Vol. 14 (pp. 281-296). Cham: Springer.

Holloway, S. L., \& Kirby, P. (2020). Neoliberalising education: New geographies of private tuition, class privilege and minority ethnic advancement. Antipode, 52(1), 164-184.

Holt, L. \& Bowlby, S. (2019). Gender, class, race, ethnicity and power in an elite girls' state school Geoforum, 105, 168-178

Hones, G. H., \& Ryba, R. H. (1972). Why not a geography of education? Journal of Geography, 71(3), 135-139.

Jahnke, H. (2005). Der italienische Mezzogiorno auf dem Weg in die europäische Wissensgesellschaft. Eine Untersuchung der Erwerbssituation und der regionalen Mobilität junger Akademiker am Beispiel Siziliens. Berliner Geographische Arbeiten: Vol. 101. Berlin.

Jahnke, H. (2014). Bildung und Wissen. In J. Lossau, T. Freytag, R. \& Lippuner (Eds.) Schlüsselbegriffe der Kultur- und Sozialgeographie. Stuttgart: UTB, 153-166.

Jahnke, H. (2019). Territorial governance of schooling and education in rural areas: Case studies from northern Germany. In H. Jahnke, C. Kramer, \& P. Meusburger (Eds.), Geographies of Schooling. Knowledge and Space, Vol. 14 (pp. 19-33). Cham: Springer.

Jahnke, H., \& Hoffmann, K. (2017). Organized after-school activities at the intersection between education and municipalities in rural areas. In A. Million, A. J. Heinrich, \& T. Coelen (Eds.), Education, space and urban planning: Education as a component of the city (pp. 339-348). Wiesbaden: Springer.

Jahnke, H., Kramer, C., \& Meusburger, P. (Eds.) (2019). Geographies of schooling. Knowledge and space, Vol. 14. Cham: Springer.

Johnston, R. J. (1994). Education, geography of. In R. J. Johnston, D. Gregory, \& D. M. Smith (Eds.), The dictionary of Human Geography. $3^{\text {rd }}$ Edition (pp. 156-157). Oxford: Blackwell.

Johnston, R. J. (2009). Education. In D. Gregory, R. Johnston., G. Pratt, M. Watts, $\&$ S. Whatmore (Eds.), The dictionary of Human Geography. $5^{\text {th }}$ Edition (pp. 186-187). Chichester: Blackwell.

Johnston, R. J., Burgess, S., Wilson, D., \& Harris, R. (2006). School and residential ethnic segregation: An analysis of variations across England's local education authorities. Regional Studies, 40(9), 973-990.

Johnston, R. J., Gregory, D., Haggett, P., Smith D. M., \& Stoddart, D. R. (Eds.). (1981). The dictionary of Human Geography. $1^{\text {st }}$ Edition. Oxford: Blackwell.

Johnston, R. J., Gregory, D., Pratt, G., \& Watts, M. (Eds.). (2000). The dictionary of Human Geography. $4^{\text {th }}$ Edition. Oxford: Blackwell.

Johnston, R. J., Gregory, D., Smith, D. M. (Eds.). (1986). The dictionary of Human Geography. 2 ${ }^{\text {nd }}$ Edition. Oxford: Blackwell.

Jöns, H. (2003). Grenzüberschreitende Mobilität und Kooperation in den Wissen- 
schaften. Deutschlandaufenthalte US-amerikanischer Humboldt-Forschungspreisträger aus einer erweiterten Akteursnetzwerkperspektive. Heidelberger Geographische Arbeiten: Vol. 116. Heidelberg: Geographisches Institut der Universität.

Jöns, H. (2018) Boundary-crossing academic mobilities in glocal knowledge economies: New research agendas based on triadic thought. Globalisation, Societies and Education, 16(2), 151-161,

Koinzer, T., Nikolai, R., \& Waldow, F. (Eds.). (2017). Private schools and school choice in compulsory education. Wiesbaden: Springer.

Kostelecká, Y., \& Hána, D. (2019). Domácí vzdělávání v kontextu evropských vzdělávacích systémi̊. Prague: Charles University.

Kovács, K. (2012). Rescuing a small village school in the context of rural change in Hungary. Journal of Rural Studies, 28(2), 108-117.

Kraftl, P. (2014) Geographies of alternative education: Diverse learning spaces for children and young people. Bristol: Bristol University Press.

Kramer, C. (1993). Die Entwicklung des Standortnetzes von Grundschulen im ländlichen Raum: Vorarlberg und Baden-Württemberg im Vergleich. Heidelberger Geographische Arbeiten: Vol. 93. Heidelberg: Geographisches Institut der Universität.

Kučerová, S. R., Bláha, J. D., \& Kučera, Z. (2015). Transformations of spatial relationships within elementary education provision: A case study of changes in two Czech rural areas since the second half of the $20^{\text {th }}$ century. Moravian Geographical Reports, 23(1), 34-44.

Kučerová, S. R., Bláha, J. D., \& Pavlasová, Z. (2015). Malé venkovské školy na trhu se základním vzděláváním: Jejich působnost a marketing na přikladu Turnovska. Sociologický časopis 51(4), 607-636.

Kučerová, S. R., Dvořák, D., Meyer, P., \& Bartůněk, M. (2020). Dimensions of centralization and decentralization in the rural educational landscape of post-socialist Czechia. Journal of Rural Studies, 74, 280-293.

Kučerová, S. R., Kučera, Z., \& Novotná, K. (2018). Formation of a regional image through geography textbooks: The case of north-west Bohemia. Norsk Geografisk Tidsskrift-Norwegian Journal of Geography, 72(3), 176-195.

Kučerová, S., Mattern, T., Štych, P., \& Kučera, Z. (2011). Změny dostupnosti základních škol v Česku jako faktor znevýhodnění regionů a lokalit. Geografie 116(3), 300-316.

Kvalsund, R. (2009). Centralized decentralization or decentralized centralization? A review of newer Norwegian research on schools and their communities. International Journal of Educational Research, 48, 89-99.

Lauko, V., Gurňák, D., Križan, F., \& Tolmáči, L. (2011). Školstvo na Slovensku v kontexte regionálnych disparit. Bratislava: Comenius University in Bratislava.

Mahon, R. (2005). Rescaling social reproduction: Childcare in Toronto/Canada and Stockholm/Sweden. International Journal of Urban and Regional Research, 29, 341357.

Mallinson, V. (1980). The Western European Idea of Education. Oxford: Elsevier.

Marissal, P. (2017). La mixité sociale résidentielle favorise-t-elle la mixité scolaire? Le cas Bruxellois. Belgeo 2-3.

Marsden, W. E. (1977). Historical geography and the history of education. History of Education, 6(1), 21-42. 
Meusburger, P. (1976). Entwicklung, Stellung und Aufgaben einer Geographie des Bildungswesens. Eine Zwischenbilanz. Mitteilungen der Österreichischen geographischen Gesellschaft, 118(1), 9-54.

Meusburger, P. (1980). Beiträge zur Geographie des Bildungs- und Qualifikationswesens: regionale und soziale Unterschiede des Ausbildungsniveaus der österreichischen Bevölkerung. Innsbruck: Institut für Geographie der Universität Innsbruck.

Meusburger, P. (1998). Bildungsgeographie. Wissen und Ausbildung in der räumlichen Dimension. Heidelberg and Berlin: Spektrum Akademischer Verlag.

Meusburger, P. (2001): Bildungsgeographie. In: Lexikon der Geographie, Band 1, Heidelberg, Berlin: Spektrum Akademischer Verlag, 162-163.

Meusburger, P. (2015). Education, Geography of. In J. D. Wright (Ed.), International Encyclopedia of the Social \& Behavioral Sciences. Second Edition (pp. 165-171). Oxford: Pergamon.

Mills, S. (2016). 'Geographies of education, volunteering and the lifecourse: the Woodcraft Folk in Britain (1925-75)'. Cultural Geographies, 23(1), pp. 103-119.

Nafaa, N. (2017). Déclin urbain et néolibéralisation de l'éducation, l'exemple de Pittsburgh aux États-Unis. Belgeo 2-3.

Nast, J. (2015). Die Öffnung der Schule. Neue Ungleichheiten zwischen Grundschulen in benachteiligten und privilegierten Nachbarschaften? Berichte. Geographie und Landeskunde, 89(2), 161-173.

Nekorjak, M., Souralová, A., \& Vomastková, K. (2011): Uvíznutí v marginalitě: Vzdělávací trh, „romské školy“ a reprodukce sociálně prostorových nerovností. Sociologický časopis, 47(4), 657-680.

Nieszery, A. (2015). Soziale und schulische Segregation in Frankreich. Strategien der sozialen Mischung in einer Gemeinde der Ile-de-France. Berichte. Geographie und Landeskunde, 89(2), 175-191.

Noreisch, K. (2007). Choice as rule, exception and coincidence: Parents' understandings of catchment areas in Berlin. Urban Studies, 44(7), 1307-1328.

Ouředníček, M., Špačková, P., \& Feřtová, M. (2011). Změny sociálního prostředí a kvality života v depopulačních regionech České republiky. Sociologický časopis, 47(4), 777-803.

Pimlott-Wilson, H., \& Coates, J. (2019). Rethinking learning? Challenging and accommodating neoliberal educational agenda in the integration of Forest School into mainstream educational settings. The Geographical Journal, 185(3), 268-278.

Ribchester, C., \& Edwards, B. (1999). The centre and the local: Policy and practice in rural education provision. Journal of Rural Studies 15(1), 49-63.

Sadovnik, A. R. (Ed.). (2011). Sociology of education. A Critical Reader. $2^{\text {nd }}$ Edition. New York and London: Routledge.

Schaefli, L., Godlewska, A., \& Christopher, L. (2019). Securing indigenous dispossession through education: An analysis of Canadian curricula and textbooks. In $\mathrm{H}$. Jahnke, C. Kramer, \& P. Meusburger (Eds.), Geographies of schooling. Knowledge and space, Vol. 14 (pp. 145-161), Cham: Springer.

Schmude, J. (1988). Die Feminisierung des Lehrberufs an öffentlichen, allgemeinbildenden Schulen in Baden-Württemberg. Heidelberger Geographische Arbeiten: Vol. 87. Heidelberg: Geographisches Institut der Universität. 
Sidorov, D. (2009). Visualizing the former Cold War ,other‘: Images of Eastern Europe in World regional geography textbooks in the United States. Journal of Educational Media, Memory, and Society, 1(1), 39-58.

Smith, D. P. (2008). The politics of studentification and '(un)balanced' urban populations: Lessons for gentrification and sustainable communities? Urban Studies, 45(12), 2541-2564.

Solstad, K. J. (1997). Equity at Risk. Oslo: Scandinavian University Press.

Tantarimäki, S. \& Törhönen, A. (2017). School network changes - what about the planning of it? A review of the school network planning in Finland's municipalities in council season 2013-2017. Foundation of the Municipal Sector, Researches No. 105. Taylor, C. (2001). Hierarchies and 'local' markets: The geography of the 'lived' market place in secondary education provision. Journal of Education Policy, 16(3), 197-214. Trnková, K., Knotová, D., \& Chaloupková, L. (2010): Málotřídní školy v České republice. Brno: Paido.

Vassal, S. (1978). La géographie de l`instruction: Peter Meusburger, Entwicklung, Stellung und Aufgaben einer Geographie des Bildungswesens. Eine Zwischenbilanz. Annales de Géographie, 87(481), 348-349.

Wahla, A. (1988). Geografie vzdělání obyvatelstva. Spisy Pedagogické fakulty $v$ Ostravě, Vol. 64. Praha: SPN.

Waldorf, R. (1986). Education, geography of. In R. J. Johnston, D. Gregory, \& D. M. Smith (Eds.), The Dictionary of Human Geography. $2^{\text {nd }}$ Edition (pp. 125-126). Oxford: Blackwell Publishers.

Warf, B., \& Arias, S., (Eds.). (2009). The spatial turn. Interdisciplinary perspectives. London a New York: Routledge.

Warrington, M. (2005): Mirage in the desert? Access to educational opportunities in an area of social exclusion. Antipode, 37(4), 796-816.

Waters, J. L. (2017). Education unbound? Enlivening debates with a mobilities perspective on learning. Progress in Human Geography, 41(3), 279-298.

Wayens, B., Marissal, P., \& Delvaux, B. (2017). Editorial: Une géographie sociale de l'enseignement / A social geography of education. Belgeo, 2-3, 1-5.

Weick, C. (1995). Räumliche Mobilität und Karriere. Eine individualstatistische Analyse der baden-württembergischen Universitätsprofessoren unter besonderer Berücksichtigung demographischer Strukturen. Heidelberger Geographische Arbeiten: Vol. 101. Heidelberg: Geographisches Institut der Universität.

\section{Authors:}

Silvie R. Kučerová

Jan Evengelista Purkyně University in Ústí nad Labem

Faculty of Science

Department of Geography

Pasteurova 15

40096 Ústí nad Labem

Czechia

Email: silvie.kucerova@ujep.cz 


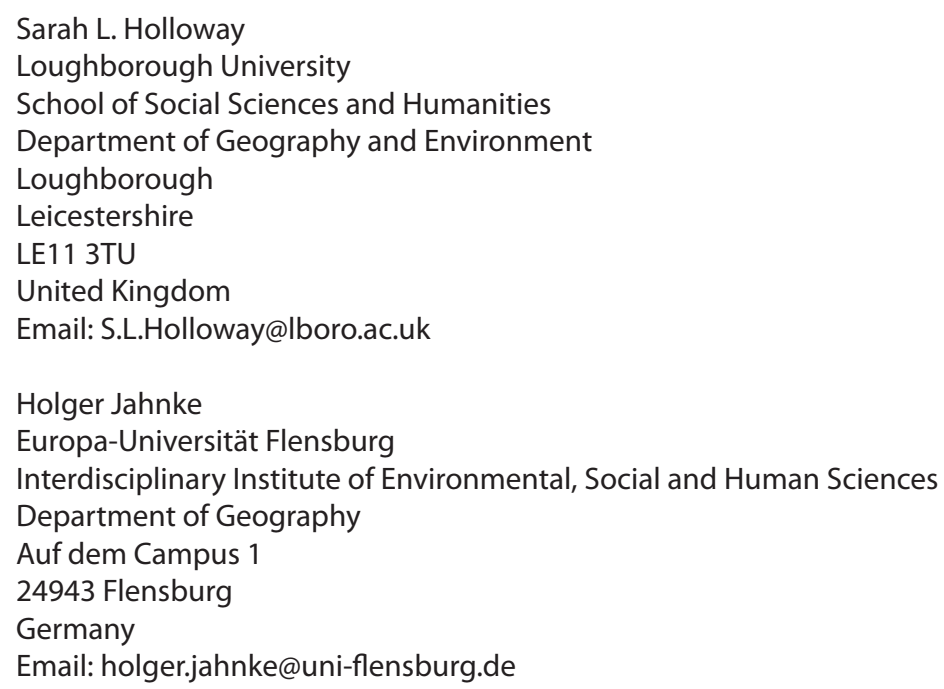

